研究速報

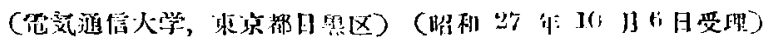

\title{
琋薄水溶液に上る電波の吸收分散 （高周波滴定のための基礎実験）
}

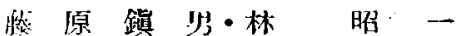

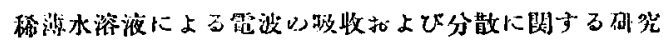

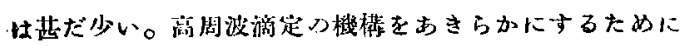

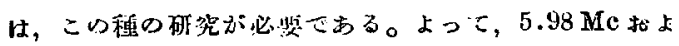
び2.54 Mc に扎いて溶液をコイル內に含む间調回路の

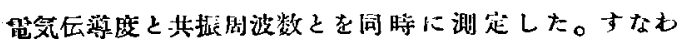

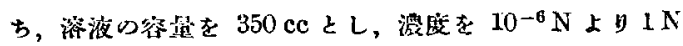
の瀄四に变えた場合，コンデンサー拮よびこのコイル から成る一つの共振回路つ共鸣曲線を测定し，之心赫大

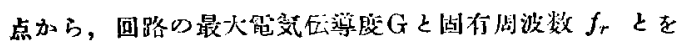

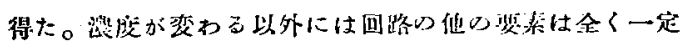

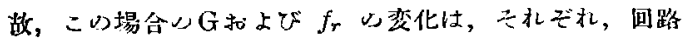

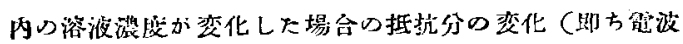

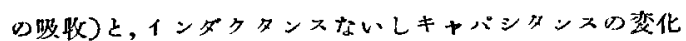

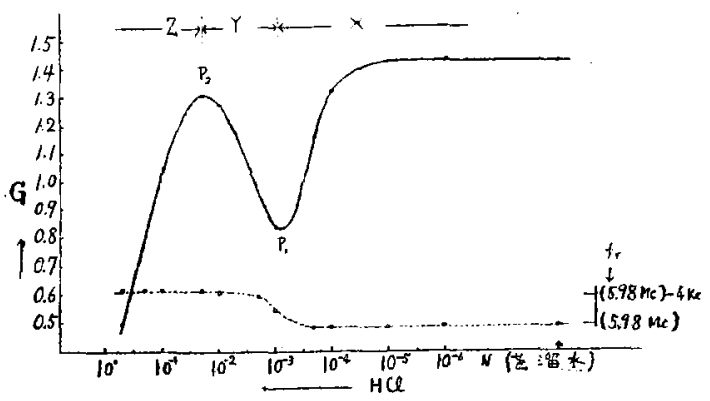

第 1 图
(即ち電波の分散)を亦すことどなる。埧酸による实駼

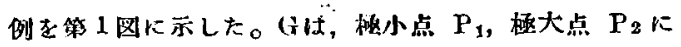
上り区分される三部分X，Y，Z加らなり， $f_{r}$ は， $\mathrm{X}$ ，

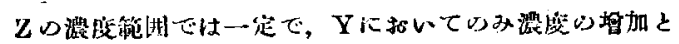

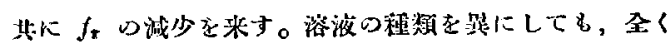
同じ㙌造心曲線が得ら机る。埙留解啠にあっては $P_{1}$,

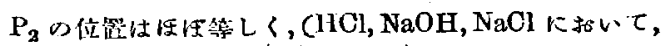

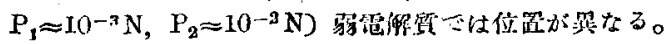

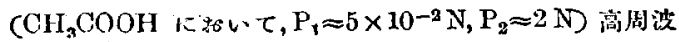

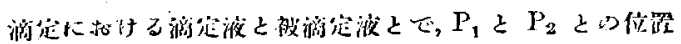

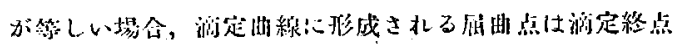

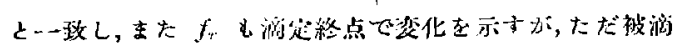

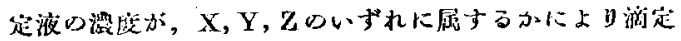

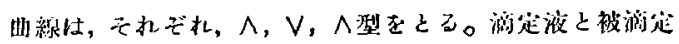

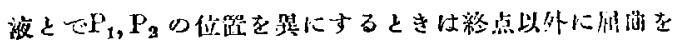

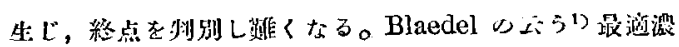

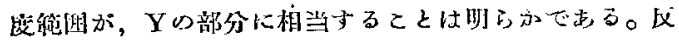

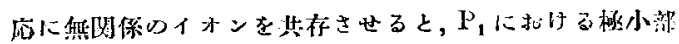
が沿天，X，Yの区别がつけ難くなる。すなおち， $\mathrm{P}_{2}$ 以

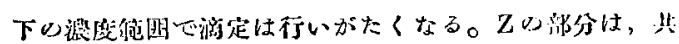

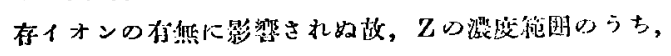
$P_{2}$ に近い部分では高周波润定を行いうる。

1) Blaedel, Mtalmstadt, Anal. Chem. 22, 794 (1950). 